\title{
COMPARATIVE STUDY ON THE USE OF DOUBLE DIFFUSION AND IMMUNOELECTROPHORESIS IN THE QUANTIFICATION OF FLAX RESISTANCE TO POWDERY MILDEW DISEASE \\ Hussein, E.M. ${ }^{1}$, A. A. Aly ${ }^{1}$, M. T. M. Mansour ${ }^{1}$, and A. A. Abde El- Fatah $^{2}$ \\ ${ }^{1}$ Plant Pathol. Res. Instit., Agric. Res. Center, Giza, Egypt. \\ ${ }^{2}$ Field Crops. Res. Instit., Agric. Res. Center, Giza, Egypt.
}

\begin{abstract}
Eight flax cultivars were evaluated for powdery mildew (PM) resistance under field conditions in 2001/2002 and 2002/2003 growing seasons. The tested cultivars could be divided into two distinct groups. The first group included the resistant cultivars Dakota, Wilden, and Williston Brown, while the second one included the susceptible cultivars Cortland, Linore, C.I.2008, Giza 7, and Giza 8. The difference in disease severity was highly significant $(p<0.01)$ between any cultivar belonged to the first group and any cultivar belonged to the second group. The antigenic relationship between Oidium lini and the fax cultivars was studied by double diffusion (DD) and immunoelectrophoresis (IE). In each method, the antiserum of infected whole plants of cultivar Giza 8 interacted against the antigens of seeds from the healthy flax cultivars. In DD test, simple linear regression analysis indicated that the common antigens between the infected Giza 8 and the healthy cultivars accounted for $86 \%$ of the total variation in severity of $\mathrm{PM}$ on the tested cultivars. On the other hand, $\mathrm{R}^{2}$ value of IE regression model was very low (15\%) and its $\mathrm{F}$. value was nonsignificant. Therefore, DD may provide a supplementary assay to field trials to distinguish between PM resistant or susceptible genotypes quantitatively.
\end{abstract}

\section{INTRODUCTION}

Powdery mildew (PM) of flax (Linum usitatissimum L.) is caused by the obligate parasite Oidium lini Škoric. This fungus is found on flax in Egypt only in its imperfect (conidial) stage. The pathogen infects all the aboveground fax organs including stems, leaves, flowers and capsules. PM occurs annually in all flax production areas in Egypt (Mansour, 1998).

Significant negative correlations were found between disease intensity ratings and agronomic traits (Aly et al., 1994). Currently, all commercially grown flax cultivars are susceptible to the disease, although field observations indicated that some experimental lines were more susceptible than others (Aly et al., 2001).

Fungicides are currently the only commercially available management practices for controlling the disease and minimizing associated losses in seed and straw yield (Aly et al., 1994 and Mansour, 1998). Complete dependence on fungicides for the disease control carries risks for the producers, in that accurate coverage and distribution of fungicides may not be achieved and there are potential problems with correct timing of application. Furthermore, increasing concern for the environment will likely mean greater regulation of pesticide usage (Pearce et al., 1996).

Use of cultivars with PM resistance can resolve all these problems. 
Currently, field evaluation is the only reliable method to distinguish flax genotypes with PM resistance. However, the precision of field evaluation of genetic resistance is adversely affected by environmental variation and heterogeneous levels of natural inoculum. In addition, field evaluation is expensive and time-consuming.

Therefore, another reliable method, either alternative or complementary to field evaluation, is required for the identification of flax genotypes with PM resistance.

In several instances, it has been found that plant hosts have antigenic substances in common with parasitic microorganisms. These substances have been termed "Common antigens" (Charudattan and DeVay, 1972). One of the theories that has been proposed to explain the primary factor in the plant-parasite interaction, which would lead either to susceptibility or resistance of the plant is the degree of antigenic parity between the plant and the pathogen. According to this concept the greater the antigenic parity between the plant and the pathogen, the greater will be susceptibility of the plant to the pathogen (Wimalajeewa and DeVay, 1971). It seems that the presence of common antigens may be an important factor that prevents triggering of the plant defense mechanism, thus allowing the pathogen to parasitize the plant (Charudattan and DeVay, 1972).

Charudattan and Devay (1972) demonstrated a common antigen relationship among Fusarium spp. and wilt-susceptible and wilt-tolerant varieties of cotton. When the common antigenic substance was isolated and purified, it was found to be polysaccharide-protein complex. It was postulated that the common antigen may be involved in the establishment and survival of Fusarium isolates in host tissue.

When the seed globulins of cotton cultivars susceptible to Fusarium wilt reacted with antiserum of $F$. oxysporum f.sp. vasinfectum, more precipitin lines were formed than with the resistant cultivars. On the other hand, no obvious reaction was detected in case of antiserum of $F$. moniliforme, which was nonpathogenic on cotton (Abd-El-Rehim et al., 1988).

Proteins of Rhizoctonia solani were compared with those of host and nonhost plants by double diffusion. Flax and Kenaf were used as host plants, while wheat, barley and sorghum were the nonhost plants. In the reactions of antiserum of $R$. solani with homologous antigen and plant antigens, among the four bands formed in the homologous reaction, two were common with the antigens of host plants. No common antigens were shared between $R$. solani and any of the nonhost plants. This result supports the concept that the greater the antigenic (protein) parity between the host and the pathogen, the greater will be the susceptibility of the host to the pathogen (Hussein et al., 1997). Shady et al. (2000) reported that common antigens were detected only between Fusarium oxysporum f.sp. vasinfectum and the susceptible cultivars Giza 71 and Giza 74, while no common bands were detected between this pathogen and the resistant cultivars Dandera, Giza 70, Giza 75, Giza 77 and Giza 85.

The present study was initiated to compare between the use of double diffusion and the use of immunoelectrophoresis in the quantification of flax resistance to powdery mildew disease. 


\section{MATERIALS AND METHODS}

\section{Evaluation of flax genotypes for PM resistance}

Experiments were conducted in 2001/2002 and 200212003 growing seasons at Giza Agricultural Research Station. Experiment consisted of a randomized complete block design of 5 replicates (blocks). Plots were $2 \times 3$ $\mathrm{m}\left(6 \mathrm{~m}^{2}\right)$ and consisted of ten rows spaced $20 \mathrm{~cm}$ apart. Seeds of each genotype were sown by hand at a rate of $70 \mathrm{~g} /$ plot. Planting dates were in the first week of December. Disease severity was rated visually in the last week of April (Nutter et al., 1991).

\section{Extraction of proteins from flax seeds}

Protein extract was prepared according to Hussein (1992) in the following way: Seeds of healthy plants of flax cultivars Giza 7, Giza 8, C.I. 2008, Linore, Cortland, Williston Brown, Wilden and Dakota were slightly ground and defatted by diethyl either or chloroform for 4 to 5 days. After drying at room temperature, ground seeds were suspended in a solution $(1-3 \mathrm{ml} / \mathrm{g}$ seeds) consisting of $12.5 \mathrm{~g}$ glucose and $1 \mathrm{~g}$ ascorbic acid dissolved in $100 \mathrm{ml}$ phosphate buffer 8.3 and ground in liquid nitrogen to a fine powder.After thawing, the powder suspended in buffer was centrifugated at 19,000 rpm for 30 minutes at $0^{\circ} \mathrm{C}$. The protein content in the supernatant was adjusted to a concentration of 3 to $4 \mathrm{mg} / \mathrm{ml}$ according to Bradford spectrophotometric method (1976) by using bovine serum albumin as a standard protein.

\section{Extraction of protein from powdery mildew-infected plants of cultivar Giza 8}

Infected fresh whole plants of flax cultivars Giza 8 was ground in liquid nitrogen to a fine powder. The grounded plants were suspended in a solution (1-3 $\mathrm{ml} / \mathrm{g}$ plants) consisting of $12.5 \%$ glucose and $1 \mathrm{~g}$ ascorbic acid dissolved in $100 \mathrm{ml}$ phosphate buffer ( $\mathrm{pH} \mathrm{8.3)}$ and contrifuged at $19000 \mathrm{rpm}$ for 30 minutes at $10^{\circ} \mathrm{C}$ (Hussein, 1992).

The protein content in supernatant was adjusted according to Bradford (1976) as previously mentioned.

\section{Immunization and preparation of antisera}

New Zealand rabbits, 3-4 kg weight, were immunized by flax antigens (infected whole plants of Giza 8). The first injection was given intracutaneously in the back between ears. This injection consisted of $0.5 \mathrm{mg}$ protein suspended in $1 \mathrm{ml}$ phosphate buffer and mixed in $1 \mathrm{ml}$ Freund's incomplete adjuvant (Difco). After one week, each animal was received $4 \mathrm{mg}$ protein administered intramuscularly every third day in the thigh in a series of twelve injections. One week after the last injection, the animal was bled in the marginal ear vein. Collected blood was kept at room temperature for 1 to $2 \mathrm{hr}$. Clots were then gently lossened and stored over night at $4^{\circ} \mathrm{C}$. Antisera were then decanted and clarified by centrifugation at $10000 \mathrm{rpm}$ for 30 minutes. 


\section{Double diffusion (DD) technique}

The technique was carried out according to Ouchterlony and Nilsson (1978). Molten $2 \%$ ionagar (Sigma), in saline $(8.5 \mathrm{~g} \mathrm{NaCl}$ to I Liter D.W.) and supplemented with merthiolate $\left(1: 10.000,37^{\circ} \mathrm{C}\right)$, was poured into $9-\mathrm{cm}$ diameter Petri dishes to obtained a layer of agar 1-2 mm thick. The diameter of the central and the peripheral wells was 10 and $5 \mathrm{~mm}$, respectively. The distance between the central well and the peripheral ones was $15 \mathrm{~mm}$. The central well was filled with infected whole plants antiserum, and the peripheral wells with antigens of healthy flax (Giza 8, C.I. 2008, Linore, Cortland, Williston Brown, Wilden, Giza 7 and Dakota). Plates were kept under humid conditions at room temperature $\left(18-24^{\circ} \mathrm{C}\right)$ in the dark for $48-72$ hours. Agar was stained with Commassie Brilliant Blue R-250 (Weeke, 1973). The developing precipitin lines were examined and recorded by hand drawing.

\section{Immunoelectrophoresis (IE) technique}

The technique was carried out according to Graber and Williams (1953). In this technique, proteins in antigen was first separated by electrophoresis in agar. Antiserum was then allowed to diffuse from a through cut in the gel parallel to the direction of electrophoresis. Immunoprecipitin arches were observed where antigen-antibody interactions occurred. Glass slides $3-5 \mathrm{~cm}$ $x 7.5 \mathrm{~cm}$ were covered with a thin layer $(2 \mathrm{~mm})$ of buffered agar gel. The gel was prepared by incorporating $1 \%$ ionagar in sodium barbital buffer $\mathrm{pH} 8.6$ to which merthiolate $(1: 10,000)$ was added to give the final concentration of $0.1 \%$. Sample wells $4 \mathrm{~mm}$ in diameter, were cut about $3.5 \mathrm{~cm}$ from the cathode. After filling the wells with antigen solution $(10 \mu \mathrm{l})$, the slide was placed in electrophoresis apparatus, which received $150 \mathrm{ml}$ of the run buffer solution (sodium barbital buffer) into each of the two troughs of the electrophoresis tank, the necessary electrical connections were made with filter paper wicks. The gel was covered with a glass plate to prevent surface evaporation. The electrophoresis was performed at 3 MA for each sample for about $2 \mathrm{hrs}$. The slides were removed from the apparatus, after termination of the electrophoresis. A channel $(5 \mathrm{~cm} \times 2 \mathrm{~mm})$ was cut between the two wells to act as trough for antiserum. The trough was filled with about $100 \mu \mathrm{l}$ of antiserum solution. The slides were kept under humid conditions at room temperature for four days in the dark. The developing precipitin archs were stained with Commassie Brilliant Blue R-250 (Weeke, 1973), recorded by hand drawing, and identified according to Ghobrial (1981) and Johnston and Thorpe (1982).

\section{Statistical analysis of the data \\ a. Field trials}

The experimental design of the field trials was a randomized complete block with five replications (Blocks). Analysis of variance (ANOVA) of the data was performed with the MSTAT-C Statistical Package (A Microcomputer Program for the Design, Management and Analysis of Agronomic Research Experiments, Michigan State Univ., USA). Least significant differences (LSD) test was used to compare cultivar means. 


\section{b. Serology test}

Regression analysis was used to measure the amount of variation in disease severity (dependent variable), which was explained by the number of common antigens (independent variable) shared between the infected Giza 8 and seeds from the healthy cultivars.

\section{RESULTS AND DISCUSSION}

Evaluation of the reaction of flax cultivars to PM (Table 1) revealed that the tested cultivars could be divided into two distinct groups. The first group included the resistant cultivars Dakota, Wilden, and Williston Brown, while the second group included the susceptible cultivars Cortland, Linore, C.I.2008, Giza 7, and Giza 8. The difference in disease severity was highly significant $(p<0.01)$ between any cultivar belonged to the first group and any cultivar belonged to the second group. Within the resistant group, the differences were nonsignificant. Giza 7 was significantly $(p<0.01)$ less susceptible than Cortland or C.I. 2008 in the susceptible group.

Table 1. Reaction of eight flax cultivars to powdery mildew disease under field conditions in El-Giza in 2001/2002 and 2002/2003 growing seasons.

\begin{tabular}{lc}
\hline Cultivar & Disease severity ${ }^{\text {a }}(\%)$ \\
\hline Dakota & 19.67 \\
Wilden & 25.11 \\
Williston Brown & 27.58 \\
Cortland & 99.48 \\
Linore & 95.26 \\
C.I. 2008 & 100.00 \\
Giza 7 & 87.26 \\
Giza 8 & 93.46 \\
\hline
\end{tabular}

a Disease severity was the percentage of infected leaves per plant in a random sample of ten plants per plot. Each value was the mean of two growing seasons. LSD $=11.19(p<0.01)$ or $8.06(p<0.05)$.

Antigenic banding patterns of DD test are shown in Fig. 1 and Table 2, while those obtained by IE are shown in Fig. 2 and Table 3. Seven bands were detected by DD. Of these bands, only two (28.57\%) were common to all the cultivars. The number of the detected bands increased to nine in IE. Two of these bands (22.22\%) were also common to all the cultivars. The cultivars showed variable decreases or increases in the number of bands when IE was used to separate the antigenic bands. However, cultivar Wilden was the only cultivar, which maintained the same number of bands whether the bands were separated by DD or by IE. 
Hussein, E. M. et al.

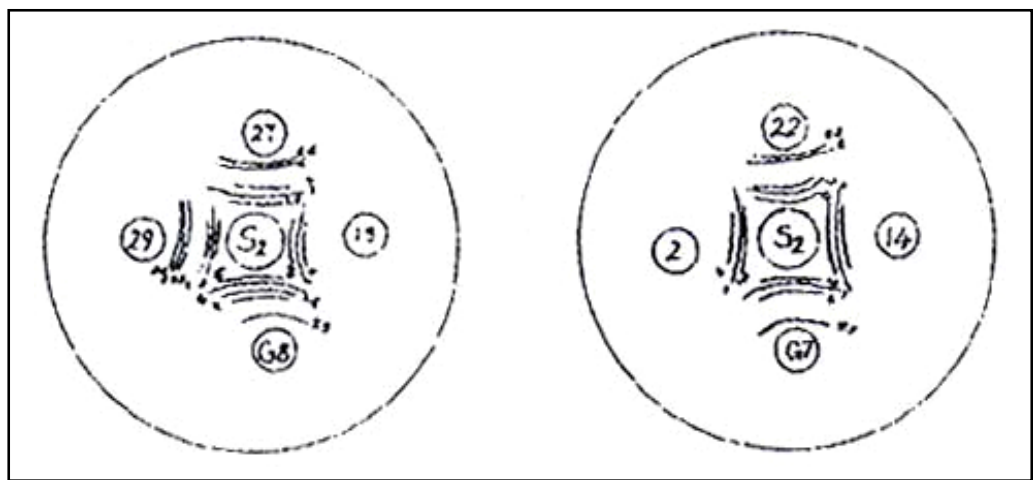

Fig.1 Diagram showing the double-diffusion reaction of antiserum $\left(S_{2}\right)$ of the infected whole plant of Giza 8 (1 and 2) against antigens of seeds from eight healthy flax cultivars.

The cultivars were: Crotland (22), Linore (27), C.I.2008 (29), Dakota (2), Wilden (14), Williston Brown (15), Giza 7 (G 7) and Giza 8 (G 8).

Table 2. Number and distribution of protein fractions obtained by double diffusion reaction of infected whole plant antiserum of Giza 8 against antigen of seeds from eight healthy flax cultivars.

\begin{tabular}{|c|c|c|c|c|c|c|c|c|}
\hline \multirow{2}{*}{$\begin{array}{c}\text { Protein } \\
\text { fraction } \\
\text { no. }\end{array}$} & \multicolumn{8}{|c|}{ Antiserum of infected Giza $8 \times$ antigens of seeds from flax cultivars } \\
\hline & Giza 7 & Giza 8 & Dakota & Wilden & $\begin{array}{c}\text { Williston } \\
\text { Brown }\end{array}$ & Cortland & Linore & C.I.2008 \\
\hline 1 & + & + & + & + & + & + & + & + \\
\hline 2 & + & + & + & + & + & + & + & + \\
\hline 3 & - & + & - & - & + & - & - & - \\
\hline 4 & + & + & + & + & - & + & + & + \\
\hline 5 & - & + & - & - & - & - & - & + \\
\hline 6 & - & - & - & - & - & + & + & + \\
\hline 7 & + & - & - & - & - & + & + & + \\
\hline
\end{tabular}

$(+)=$ Protein fraction was present

$(-)=$ Protein fraction was absent.

Some views (Doubly et al., 1960 and DeVay et al., 1967) on the occurrence of common antigens between host and pathogen emphasized a quantitative relationship in regard to their effect on disease susceptibility. In the present study, this quantitative relationship has been confirmed by the application of regression analysis, which indicated that the common antigens between infected Giza 8 and the healthy cultivars in DD test accounted for $86 \%$ of the total variation in PM severity on the cultivars (Table 4 and Fig. 3 ). On the other hand, $R^{2}$ value of the IE regression model was very low and its F. value was nonsignificant (Table 4). 


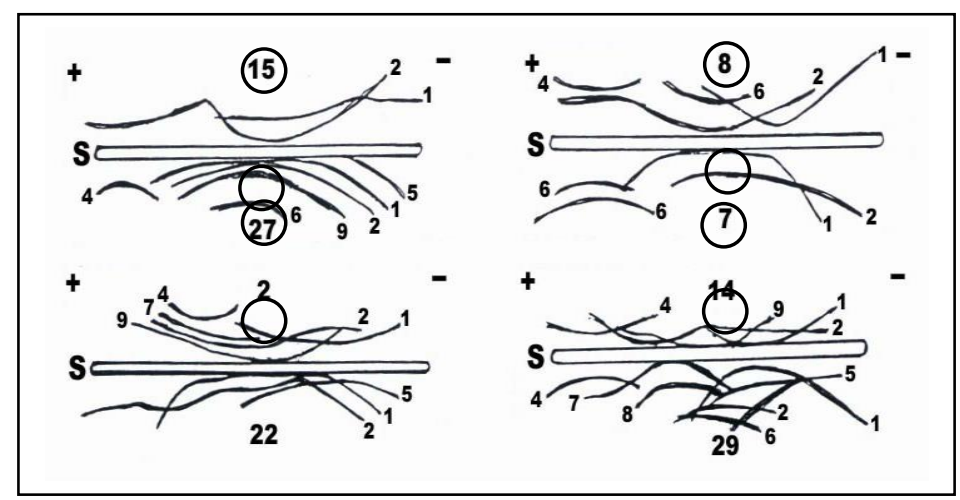

Fig.2 Immunoelectrograms of the fractionated proteins resulting from the reaction of the antiserum (S) of powdery mildew-infected whole plants of Giza 8 against seed antigens from eight healthy flax cultivars. The protein fractions were IgM globulin (1), $\alpha-2-$ macroglobulin (2), haptoglobulin (3), transferrin 6 (4), $\alpha-2$ lipoprotein (5), $\alpha$ - haploglobulin (6), $\alpha-1$ - haploglobulin (7), $\alpha-2$ haploglobulin (8), and $\alpha-2-$ haptoglobulin (9). The tested cultivars were Dakota (2), Wilden (14), Williston Brown (15), Cortland (22), Linore (27), C.I.2008 (29), Giza 7 (7), and Giza 8 (8).

Table 3. Number and distribution of protein fractions obtained by immunoelectrophoretic reaction of infected whole plant antiserum of Giza 8 against antigen of seeds from eight healthy flax cultivars.

Protein Antiserum of infected Giza $8 \times$ antigens of seeds from flax cultivars

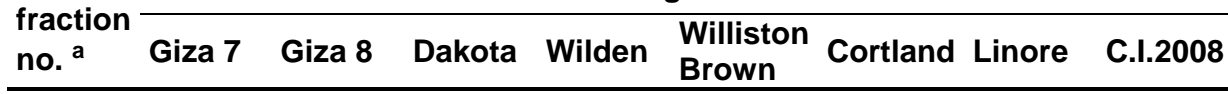

\begin{tabular}{|c|c|c|c|c|c|c|c|c|}
\hline 1 & + & + & + & + & + & + & + & + \\
\hline 2 & + & + & + & + & + & + & + & + \\
\hline 3 & - & + & - & - & - & - & - & - \\
\hline 4 & + & + & + & + & - & - & + & + \\
\hline 5 & - & - & - & - & - & + & + & + \\
\hline 6 & - & - & - & - & - & - & + & + \\
\hline 7 & - & - & + & - & - & - & - & + \\
\hline 8 & - & - & - & - & - & - & - & + \\
\hline 9 & - & - & + & - & - & - & + & - \\
\hline
\end{tabular}


Hussein, E. M. et al.

Table 4. Regression equations that describe the effect of some antigenic protein fractions $\left(X_{s}\right)$ on severity ${ }^{a}$ of flax powdery mildew.

\begin{tabular}{lllll}
\hline $\begin{array}{l}\text { Method of protein } \\
\text { fractionation }\end{array}$ & Regression equation & $\mathrm{R}^{2}$ & $\mathrm{~F}$. value & $\mathrm{P}>\mathrm{F}$ \\
\hline Double diffusion & $\mathbf{Y}=-55.66+29.18 \mathbf{X}$ & 0.86 & 35.15 & 0.001 \\
Immunoelectrophoresis & $\mathbf{Y}=33.99+8.34 \mathbf{X}$ & 0.15 & 1.06 & 0.34 \\
\hline
\end{tabular}

${ }^{a}$ PM severity was measured as the percentage of infected leaves/plant in a random sample of 10 plants/plot.

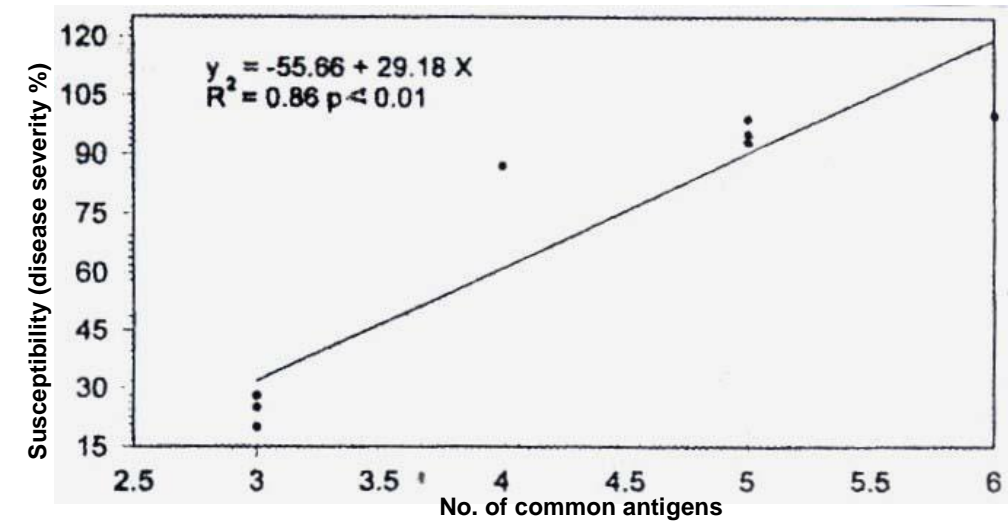

Fig. 3. Regression equation that describes the relationship between number of common antigens $(x)$ found in Oidium lini-infected whole plants of flax cultivar Giza 8 and in seeds from healthy cultivars and susceptibility $(\mathrm{Y})$ of these cultivar to $O$. lini.

There were two sources of the protein fractions shown in Tables 2 and 3. Some of these fractions were the common antigens shared by $O$. lini and flax cultivars, while the remaining fractions could be attributed to the interaction between the antibodies of Giza 8 and the antigens of the other flax cultivars. Consequently, the elimination of Giza 8 antibodies from the antiserum of infected Giza 8 by the reciprocal precipitation would decrease the number of the observed protein fractions. In this case, the remaining fractions would represent the common antigens shared by $O$. lini and the tested flax cultivars. In the present study, Giza 8 antibodies were not eliminated from the antiserum of infected Giza 8 because our previous studies (Hussein et al., 2003) indicated that this procedure did not increase the $R^{2}$ value of the regression model.

At this point, the question that may arise is which method is better for the quantification of PM severity on the tested cultivars? DD test was evidently superior to IE for two reasons. DD test did not require the application of electrophoresis, which greatly simplified the test. In addition, its regression model gave high $\mathrm{R}^{2}$ value, which implies that it was a reliable test for predicting PM severity. On the contrary, these advantages were 
completely lacking when IE was used for the quantification of PM severity. Therefore, DD may provide a supplementary assay to field trials to distinguish between PM resistant or susceptible genotypes quantitatively.

\section{ACKNOWLEDGEMENT}

This research was supported by the Research Project No. EU. 13.74.96 (Integrated Control of Principal Flax Diseases in Egypt).

\section{REFERENCES}

Abd-El-Rehim, M.A., E.M. Abou-Taleb, and A. Tohamy. 1988. Common antigen(s) in cotton to Fusarium oxysporum f.sp. vasinfectum. J. Phytopathol., 121:217-223.

Aly, A.A., A.Z.A. Ashour, E.A.F. El-Kady and M.A. Mostafa. 1994. Effectiveness of fungicides for control of powdery mildew of flax and effect of the disease on yield and yield components. J. Agric. Sci. Mansoura Univ., 19: 4383-4393.

Aly, A.A., S.H. Mostafa, and M.T.M. Mansour. 2001. Effect of powdery mildew disease on yield and yield components of some flax lines. J. Agric. Sci. Mansoura Univ., 26: 7711-7725.

Bradford, M.M. 1976. A rapid and sensitive method for the quantification of microgram quantities of protein utilizing the principle of protein-dye binding. Anal Biochem., 72: 248-254.

Charudattan, R. and J.E. DeVay. 1972. Common antigen among varieties of Gossypium hirsutum and isolates of Fusarium and Verticillium species. Phytopathology, 62:230-234.

DeVay, J.E., W.C.S. Schnathorst, and M.S. Foda. 1967. VI. Protein metabolism in the host. Common antigens and host-parasite interactions. Pp. 313-328. In: The Dynamic Role of Molecular Constituents in Plant-Parasite Interactions (C.J. Mirocha and I. Uritani, eds.) Bruce Publishing Co., St. Paul, Minn.

Doubly, J.A., H.H. Flor, and C.O. Clagett. 1960. Relation of antigens of Melampsora lini and Linum usitatissimum to resistance and susceptibility. Science, 131:229.

Ghobrial, W.N. 1981. Studies on symbiotic nitrogen fixation. Ph.D. Thesis, Mansoura Univ., Mansours, $137 \mathrm{p}$.

Graber, P.et C.A. Williams. 1953. Methode Permettant l'etude conjugee des proprietes electrophoretiques et immunochimiques d'un mélange de proteins. Application au serum sanguine. Biochim. Biophys. Acta, 10:193-194.

Hussein, E.M. 1992. Biochemical and serological studies for determining susceptibility of cotton cultivars to Fusarium oxysporum f.sp. vasinfectum. (In Russian). Ph.D.Thesis, All-Union Institute of Plant Protection, Leningrad, USSR.

Hussein, E.M., A.A. Aly, M.A. Tag El-Din, and A.Z.A. Ashour. 1997. Comparative studies on serological and electrophoretic protein patterns of Rhizoctonia solani and its host and nonhost plants. J. Agric. Sci., Mansoura Univ., 22:581-593. 
Hussein, E.M., A.A. Aly, and S.M.E. Zayed. 2003. Use of serological interactions to quantify resistance of flax cultivars to powdery mildew disease. J. Agric. Sci. Mansoura Univ. 28:6655-6663.

Johnstone, A. and R. Thrope. 1982. "Immunochemistry in Practice". Blackwell Scientific Publications, Oxford. 298 p.

Mansour, M.T.M. 1998. Pathological studies on powdery mildew of flax in A.R.E. Ph.D. Thesis, Fac. Agric., Zagazig Univ. Moshtohor. 148 pp.

Nutter, F.W., Jr. P.S. Teng, and F.M. Shoks. 1991. Disease assessment terms and concept. Plant Dis. 75: 1187-1188.

Ouchterlony, O. and A.L. Nillson. 1978. Immunodiffusion and immunoelectrophoresis. P. 190. In: Handbook of Experimental Immunology (D.M. Weir, ed.). $3^{\text {rd }}$ ed. Blackwell Scientific Publications, Oxford.

Pearce, W.L., D.H. Van Sanford, and D.E. Hershman. 1996. Partial resistance to powdery mildew in soft red winter wheat. Plant Dis. 80: 1359-1362.

Shady, A.I., E.M. Hussein, M.A. Tag El-Din, and M.I. Sarwat. 2000. Electrophoretic and serological evaluation of some cotton cultivars for their resistance to Fusarium wilt disease. Arab Univ. J. Agric. Sci., Ain Shams Univ., Cairo, 8:439-455.

Weeke, B. 1973. Immuno-electrophoresis and cross immunoelectorphoresis. Scand. J. Immuno. Suppl. 1:37-47.

Wimalajeewa, D.L.S. and J.E. DeVay. 1971. The occurrence and characterization of a common antigen relationship between Ustilago maydis and Zea mays. Physiol. PI. Pathol. 1:523-535.

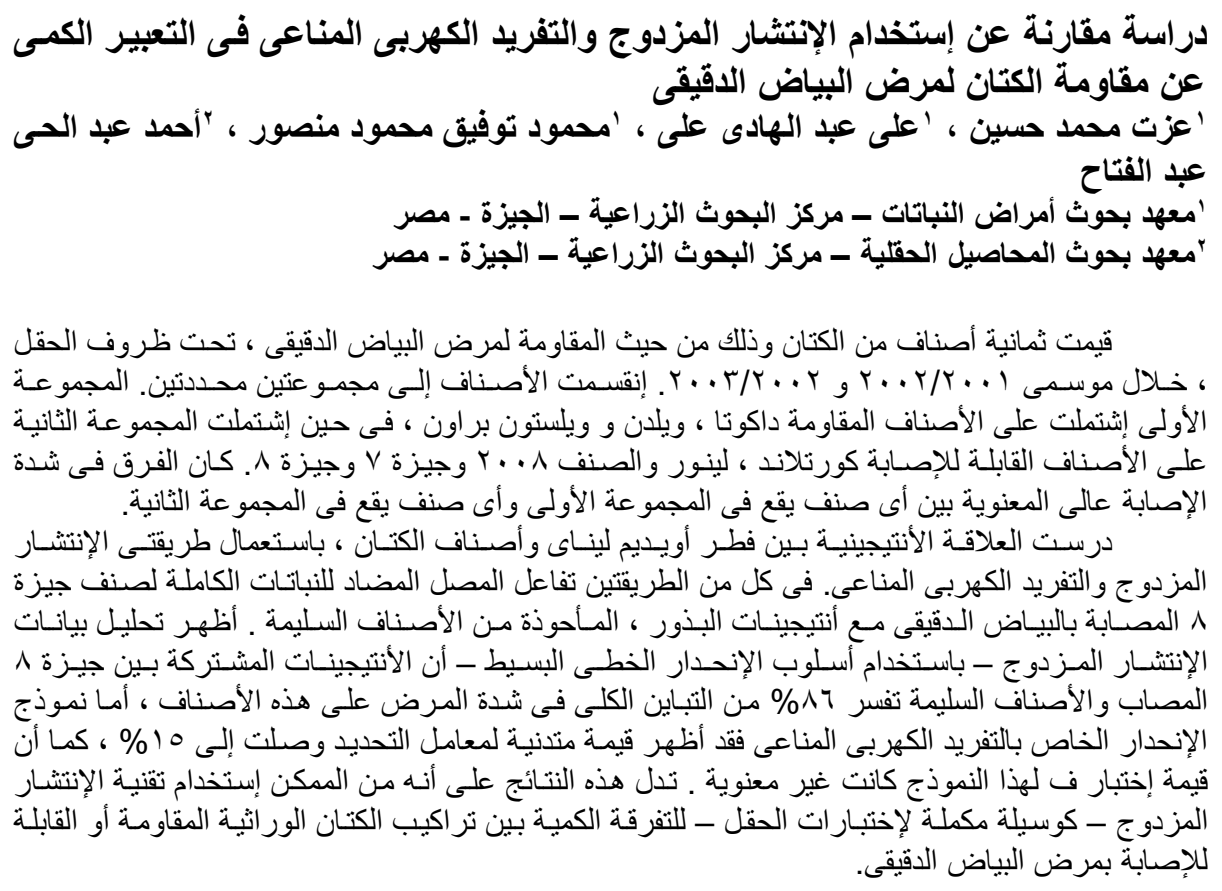

